\title{
Redescription of gnaphosids (Aranei: Gnaphosidae) described by O. Pickard-Cambridge from the material of the Second Yarkand Mission
}

\section{Переописание гнафозид (Aranei: Gnaphosidae) описанных О. Пикардом-Кембриджем по материалам, собранным в ходе Второй Яркендской Миссии}

\author{
Yuri M. Marusikk,2, Mikhail M. Omelko ${ }^{3,4}$ \\ Ю.М. Марусик ${ }^{1,2}$, М.М. Омелько
}

\footnotetext{
${ }^{1}$ Institute for Biological Problems of the North, Portovaya Street 18, Magadan 685000, Russia. E-mail: yurmar@mail.ru

${ }^{1}$ Институт биологических проблем Севера, ДВО РАН, ул. Портовая, 18, Магадан, 685000 Россия.

${ }^{2}$ Department of Zoology \& Entomology, University of the Free State, Bloemfontein 9300, South Africa.

${ }^{3}$ Far Eastern Federal University, Sukhanova 8, Vladivostok 690950, Russia.

3 Дальневосточный Федеральный Университет, Суханова 8, Владивосток, 690950 Россия.

${ }^{4}$ Federal Scientific Center of East Asia Terrestrial Biodiversity, Far Eastern Branch, Russian Academy of Sciences, Vladivostok 690022, Russia. E-mail: omelkom@gmail.com

${ }^{4}$ Федеральный научный центр Биоразнообразия наземной биоты Восточной Азии ДВО РАН, Владивосток 690022, Россия.
}

KEY WORDS: Araneae, spider, Pamir, Himalaya, Tibet, new combination, new synonym.

КЛЮЧЕВЫЕ СЛОВА: Araneae, пауки, Памир, Гималаи, Тибет, новая комбинация, новый синоним.

ABSTRACT. Twelve gnaphosid species have been described by O. Pickard-Cambridge [1885] from Himalaya and Pamir. Of them only two Gnaphosa have been redescribed based on the types. Ten other species: eight species placed in Drassus Walckenaer, 1805 and two in Micaria Westring, 1851 have been never studied since their description. Study of types represented by adults reveals that at least four species placed in Drassus and later in Drassodes Westring, 1851 are misplaced. Two new combinations are suggested: Coreodrassus interlisus (O. Pickard-Cambridge, 1885) comb.n. and Echemus interemptor (O. Pickard-Cambridge, 1885) comb.n. (both ex. Drassodes). Drassodes infletus known only from females may belong to Echemus Simon, 1878. Taxonomic position of D. involutus remains uncertain. Drassodes lapsus (O. Pickard-Cambridge, 1885) syn.n. described based on a subadult female is synonymized with $D$. invisus, a species described from the same region. Drassodes dispulsoides Schenkel, 1963 syn.n. and D. parauritus Song, Zhu et Zhang, 2004 syn.n. are synonymized with $D$. dispulsus (O. Pickard-Cambridge, 1885). It was found that Micaria connexa O. Pickard-Cambridge, 1885 syn.n. and M. pallida O. Pickard-Cambridge, 1885 syn.n. are synonyms with M. lenzi Bösenberg, 1899. Although these names are senior synonyms of M. lenzi, because of the lack of usage of these names [ICZN, 2019: Art. 23.9.1] vs. wide usage of M. lenzi we preserve the junior synonym as the valid name. Type localities of six species described by O. Pickard-Cambridge are indicated incorrectly in the World Spider Catalog and are rectified here. A new combination is suggested for Echemus incinctus Simon, 1907, a spe- cies known from Western Africa: Hongkongia incincta (Simon, 1907), comb.n.

How to cite this article: Marusik Yu.M., Omelko M.M. 2019. Redescription of gnaphosids (Aranei: Gnaphosidae) described by O. Pickard-Cambridge from the material of the Second Yarkand Mission // Arthropoda Selecta. Vol.28. No.2. P.277-290. doi: 10.15298/ arthsel. 28.2.11

РЕЗЮМЕ. О. Пикард-Кембридж описал 12 видов гнафозид из Гималаев и Памира [1885]. Из них только два вида рода Gnaphosa были переописаны на основе изучения типов. Десять других видов: восемь видов, помещённых в род Drassus Walckenaer, 1805 и два в Micaria Westring, 1851 никогда не изучались. Изучение типов, представленных половозрелыми особями, показало, что по меньшей мере четыре вида помещены в род Drassus и позднее в Drassodes Westring, 1851 ошибочно. Предложены две новые комбинации: Coreodrassus interlisus (O. Pickard-Cambridge, 1885) comb.n. и Echemus interemptor (O. Pickard-Cambridge, 1885) comb.n. (оба ex. Drassodes). Drassodes infletus известный по самкам может относится к роду Echemus Simon, 1878. Таксономическая позиция D. involutus остаётся неясной. Drassodes lapsus (O. PickardCambridge, 1885) syn.n. описанный по субадультным самкам синонимизирован с D. invisus, видом из того же региона. Drassodes dispulsoides Schenkel, 1963 syn.n. и D. parauritus Song, Zhu et Zhang, 2004 syn.n. синонимизированы с D. dispulsus (O. PickardCambridge, 1885). Было обнаружено, что Micaria connexa O. Pickard-Cambridge, 1885 syn.n. и $M$. 
pallida O. Pickard-Cambridge, 1885 syn.n. являются синонимами M. lenzi Вцsenberg, 1899. Хотя эти названия являются старшими синонимами M. lenzi, но так как они не используются [ICZN, 2019: Art. 23.9.1] vs. широкое использование M. lenzi мы сохраняем младший синоним в качестве валидного названия. Типовые местообитания шести видов описанных в работе в Мировом Каталоге Пауков указаны неверно и поправлены здесь. Новая комбинация предложена для Echemus incinctus Simon, 1907, вида известного из Западной Африки: Hongkongia incincta (Simon, 1907), comb.n.

\section{Introduction}

Octavius Pickard-Cambridge [1885] made the first survey of spiders from Indian Himalaya, Pamir and southwestern Xinjiang. This survey was based on material collected during the Second Yarkand Mission (1873-1874) by Dr. Ferdinand Stoliczka. 132 species have been recognized among this material and 107 of them have been described as new to science [WSC, 2019]. The majority of these species remain known only from the original publication and and are without figures. The lack of redescriptions is chiefly caused by the absence of species name and geographical labels in the vials containing spiders collected during the Second Yarkand Mission [Proszyński, Żochowska, 1981; Marusik, 1993, 2017, Marusik et al., 2018; Marusik, Nadolny, 2018; Marusik, Omelko, 2018; Marusik, Zonstein, 2019] making the material difficult to locate and identify within the collection. All vials contain labels stating just the bottle number, vial number, and sometimes, the number of specimens. A search of the $\mathrm{O}$. Pickard-Cambridge archive in the Oxford University Museum of Natural History (UK) failed to reveal any notes that enable such numerical labels to be deciphered. So far only species of few families have been revised: Saliticidae [Proszyński, Żochowska, 1981], Thomisidae, Philodromidae and Sparassidae [Marusik, 1993], and some other families represented by a single species. Because of these difficulties, we decided to revise the collection step by step with the goal to restore species names and provide detailed redescriptions of the types.

This paper is devoted to Gnaphosidae. O. PickardCambridge [1885] described 12 species of this family: Drassus Walckenaer 1805 (8 species), Gnaphosa Latreille, 1804 (2 species) and Micaria Westring, 1851 (2 species) and reported three more species belonging to Drassus, Gnaphosa and Prosthesima L. Koch, 1872. Since then only the two Gnaphosa species have been redescribed based on the type material [Ovtsharenko et al., 1992]. Two species of Drassus, namely D. lapsus and $D$. dispulsus were redescribed based on specimens from China but not on the syntypes [Hogg, 1902; Schenkel, 1936]. Identification of the former species was doubted by Hogg [1912].

Among the material studied we located only seven Drassus species and one Micaria.
In general, it was not difficult to recognize gnaphosids due to the illustrations provided by O. PickardCambridge. Such illustrations however, are lacking for majority of the families treated in the publication (i.e. Salticidae, Thomisidae, Araneidae, Lycosidae, etc.). We found it confusing that the number of localities mentioned in the text does not correspond to the number of the vials. Another point that brings some difficulties to the species recognition is lack of information on how many specimens have been studied. O. Pickard-Cambridge indicated only the sex of specimen(s), and if certain species was represented by numerous specimens, juveniles where not mentioned.

In the time when O. Pickard-Cambridge [1885] wrote the paper "Drassus" (Drassodes) had very wide limits and encompassed species now considered to be in many other genera and even families. For example, Drassus troglodites C.L. Koch, 1839 reported in the paper, is now considered to be in Haplodrassus, as $H$. signifer C.L. Koch, 1839. While studying types we recognized that only three species still belong to Drassodes, two species now belong to Coreodrassus Paik, 1984 and Echemus Simon, 1878 and three others can be assigned to this genus only with large reservations.

\section{Material and methods}

Specimens were photographed with a Canon EOS 7D camera attached to an Olympus SZX16 stereomicroscope and Pro-Microscan camera attached to an Olympus BH-2 stereomicroscope. Digital images were mounted using Zerene Stacker and Helicon Focus 3.10 image stacking software. Epigynes were cleared in a $\mathrm{KOH} /$ water solution until the soft tissues were dissolved. Standard abbreviations are used for leg segments: $\mathrm{Fe}$ - femur, $\mathrm{Pa}$ - patella, $\mathrm{Ti}$ - tibia, $\mathrm{Mt}$ - metatarsus, Ta - tarsus. In material examined the following original abbreviations have been used: B - bottle, $\mathrm{v}$ — vial, sp — [number of] specimen(s). The meaning of some of the numbers and letters on the labels are unclear to us or the museum curator. All taxa treated here are listed in alphabetical order of genera and species.

All material treated here belongs to the Oxford University Museum of Natural History, United Kingdom (OUMNH).

\section{Taxonomic survey}

\section{Coreodrassus Paik, 1984}

TYPE SPECIES: Coreodrassus coreanus Paik, 1984 (=C. lancearius (Simon, 1893)).

COMMENTS. Currently three species occurring in Asia are placed in this genus [WSC, 2019]. Although the habitus of these spiders are similar to those in Drassodes, the copulatory organs of females and in particular males, are very different and, in some respects, unique (long palpal patellar apophysis and two retrolateral apophyses).

Coreodrassus interlisus (O. Pickard -Cambridge, 1885) comb.n.

Figs 1A, 2E, 7A-B

Drassus i. O. Pickard-Cambridge, 1885b: 12, pl. 1, f. 9 ( (O'P). 


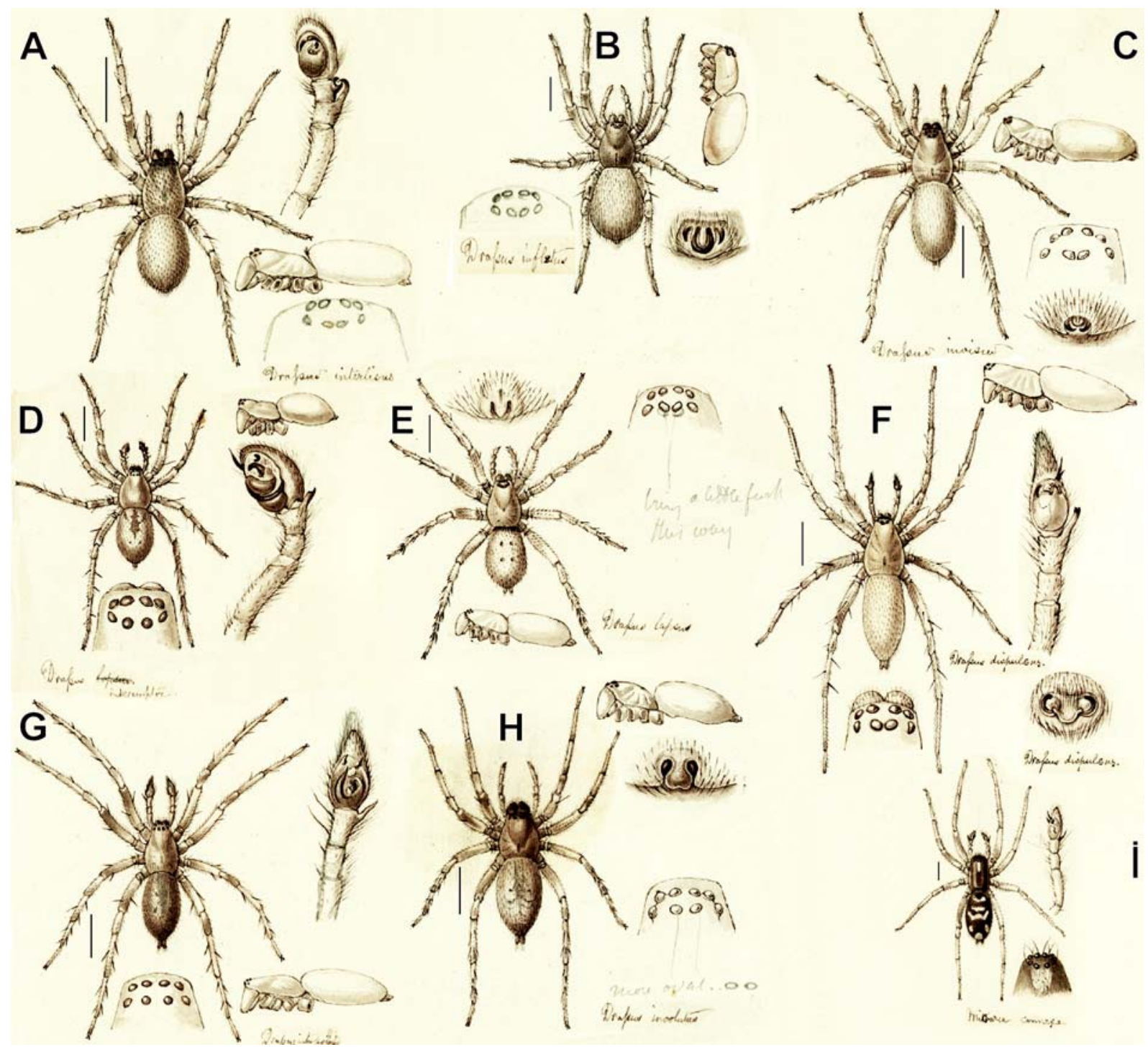

Fig. 1. Copies of original figures by O. Pickard-Cambridge with his handwritten comments: Drassus interlisus (A), D. infletus (B), D. invisus (C), D. interemptor (D), D. lapsus (E), D. dispulsus $(\mathrm{F})$, D. interpolator $(\mathrm{G})$, D. involutus $(\mathrm{H})$ and Micaria connexa (I).

Рис. 1. Копии оригинальных рисунков О. Пикарда-Кембриджа с рукописными комментариями автора: Drassus interlisus (A), D. infletus (B), D. invisus (C), D. interemptor (D), D. lapsus (E), D. dispulsus (F), D. interpolator $(\mathrm{G})$, D. involutus $(\mathrm{H})$ и Micaria connexa (I).

Drassodes i: Reimoser, 1919: 198.

MATERIAL EXAMINED. Syntypes: 2 +o with labels “ $376, \mathrm{~B}$ 376 v10 1sp" and "B 378 v11 1sp, D53".

LOCALITIES MENTIONED IN THE TEXT: Kashghar, December 1873; Yarkand, 21st to 27th May 1874; between Yangihissar and Sirikol, March 1874; neighbourhood of Leh, August or September 1873; Yarkand to Bursi, between May 28th and June 17 th, 1874.

ETYMOLOGY. Seems derived from a Latin verb interlido meaning "to strike out" or "to strike against".

NOTE. O. Pickard-Cambridge [1885] listed this species from 5 localities in Xinjiang and India, although we found only 2 vials with 2 females. The male was not found. It may be that some other specimens were identified based on juveniles.

While describing this species O. Pickard-Cambridge [1885] doubted whether it truly belonged to Drassus and compared it with Hypsinotus L. Koch, 1866 a genus now considered as a synonym of Corinna C.L. Koch, 1841 (Corinnidae). Figure of the male palp (Fig 1A, and fig. 9c in O. Pickard-Cambridge, 1885) with patellar and two tibial apophyses leaves no doubt that this species belongs to Coreodrassus. Coreodrassus interlisus is very similar to C. semidesertus Ponomarev et Tsvetkov, 2006 known from Northwestern Kazakhstan and to C. forficalis Zhang et Zhu, 2008 known from northern Xinjiang. These three species could prove to be synonyms upon further study. Coreodrassus interlisus is lacking proper figures of the male palp, and figure of the epigyne of $C$. semidesertus is too schematic to be compared with $C$. interlisus.

DESCRIPTION. Male. Syntype male not found.

Female. Total length 9.10-10.50. Carapace 3.90-4.50 long, 2.80-3.45 wide.

Chelicerae with 3 promarginal and 2 (one of them very small) retromarginal teeth. 


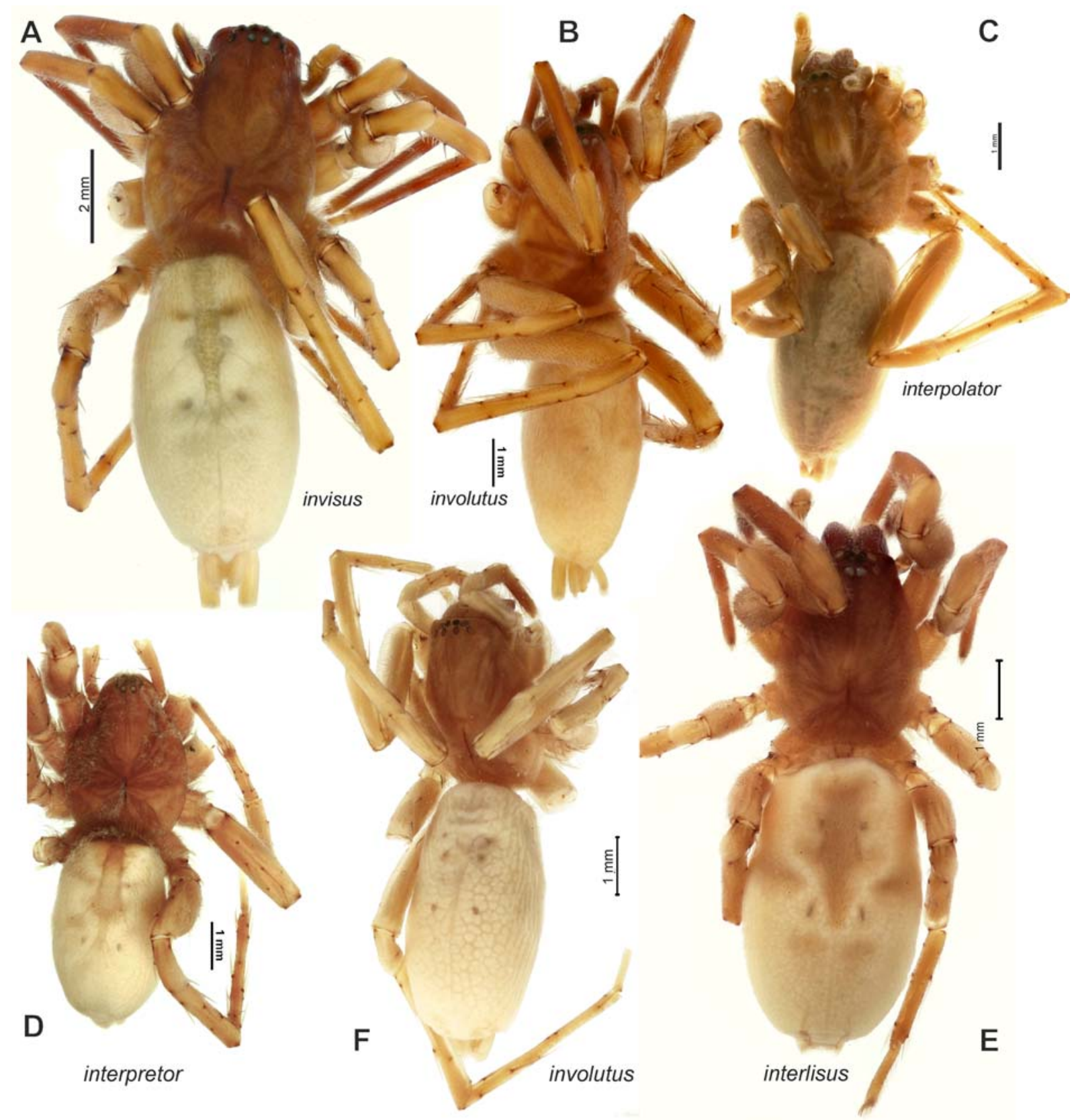

Fig. 2. Habitus of Drassodes invisus (A), D. dispulsus (B), D. interpolator (C), D. interemptor (D), D. interlisus (E) and D. involutus (F), dorsal view. A, E, F - females; B-D - males.

Рис. 2. Внешний вид Drassodes invisus (A), D. dispulsus (B), D. interpolator (C), D. interemptor (D), D. interlisus (E) и $D$. involutus (F), дорзально. А, Е, F - самки; В-D - самцы.

Length of palp and leg segments (? - refers to missing segment).

\begin{tabular}{|l|c|c|c|c|c|c|}
\hline & $\mathrm{Fe}$ & $\mathrm{Pa}$ & $\mathrm{Ti}$ & $\mathrm{Mt}$ & $\mathrm{Ta}$ & Total \\
\hline I & 3.15 & 2.05 & 2.88 & 2.05 & 1.38 & 11.50 \\
\hline II & 2.85 & 1.75 & 2.50 & 1.93 & 1.33 & 10.35 \\
\hline III & $?$ & $?$ & $?$ & $?$ & $?$ & - \\
\hline IV & 3.38 & 1.88 & 2.70 & 3.45 & 1.63 & 13.03 \\
\hline
\end{tabular}

Leg spination (? - refers to missing segment): femora I $2 \mathrm{~d} 1 \mathrm{p}$, II $2 \mathrm{~d} 1 \mathrm{p}$, III ?, IV 2d1r; tibia I 0, II 0, III ?, IV 2p3r2$2 \mathrm{v}$; metatarsus I 0 , II 0, III ?, IV 3p3r2-2v.

Epigyne as in Figs 7A-B; epigynal plate with shallow posterior notch $(T n)$; fovea (depression) developed only in anterior part of the epigynal plate, divided by broad septum $(\mathrm{Se})$ into 2 separate parts, antero-lateral parts of fovea with small pockets $(A p)$, copulatory openings located in the center of the plate; with small lateral pockets $(L p)$.

DISTRIBUTION. WSC [2019] indicates its distribution as Yarkand, although species was described and known so far from Yarkand and India (Leh). 

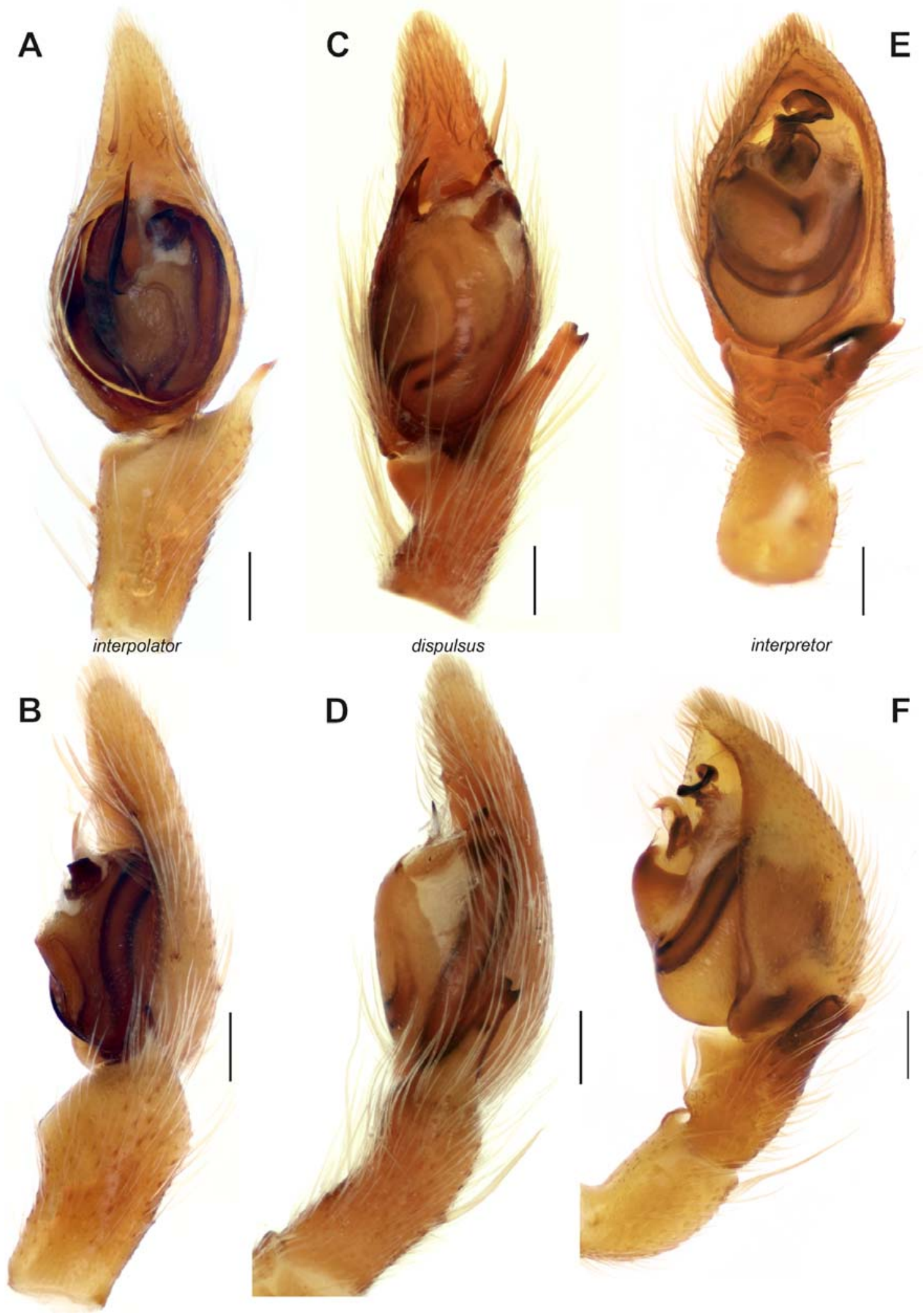

Fig. 3. Male palp of Drassodes interpolator (A, B), D. dispulsus (C, D) and Echemus interemptor (E, F). A, C, E - ventral view; D, $\mathrm{D}, \mathrm{F}$ - retrolateral view. Scale $=0.2 \mathrm{~mm}$.

Рис. 3. Пальпа самца Drassodes interpolator (А, В), D. dispulsus (C, D) и Echemus interemptor (Е, F). А, С, Е — вентрально; D, D, F - ретролатерально. Масштаб 0,2 мм. 


\section{Drassodes Westring, 1851}

TYPE SPECIES: Aranea lapidosa Walckenaer, 1802.

COMMENTS. For a long time Drassus Walckenaer, 1805 (=Gnaphosa Latreille, 1804) was a 'waste-basket', not only for gnaphosid species, but also for Agelenidae, Dictynidae, Cheiracanthiidae, Clubionidae, Corinnidae, Liocraniidae, Oecobiidae, Sparassidae and Zodariidae [cf. Bonnet, 1956]. At the time when O. Pickard-Cambridge wrote his work [1885] and until at least 1932 the type species of Drassodes was considered in Drassus. Therefore, it is not strange that O. Pickard-Cambridge [1885] placed eight new species with similar habitus and lacking pattern in Drassus. Examination of types reveals that at least four of the species belong elsewhere. We were able to recognize the proper genus for only two of them, D. interlisus and D. interemptor. Although the two other species are not related to Drassodes and represent three, most likely new genera, we are not describing them because all these species are represented by specimens of only one sex and there are several poorly known genera from the region, for example Coillina Yin et Peng, 1998 (known from male only, Yunnan) or Ladissa Simon, 1907 (India, there are no figures of the generotype).

\section{Drassodes dispulsus (O. Pickard-Cambridge, 1885)} Figs 1F, 2B, 3C-D, 4C-D, 5B, 6A-C.

Drassus d. Pickard-Cambridge, 1885: 11, pl. 1, f. 8 ( ( $\left.{ }^{7}+\right)$. Drassodes d.: Schenkel, 1936: 252, f. 82 (†).

Scotophaeus d.: Reimoser, 1935: 173 (transferred to Scotophae$u s)$.

Drassodes dispulsoides Schenkel, 1963: 32, f. 13 (†). Syn.n. D. auratus: $\mathrm{Hu}, \mathrm{Wu}, 1989: 255$, f. 208.1-4 (o'o, misidentified).

D. auratus: Hu, 2001: 232, f. 124.1-4 ( $\bigcirc^{7}$, , misidentified).

D. parauritus Song, Zhu et Zhang, 2004: 69, 315, f. 36A-E $\left(\sigma^{\top}+\right)$. Syn.n.

D. dispulsoides: Song et al., 2004: 53, 312, f. 26A-I (+; not $\bigcirc^{\top}$, mismatched).

MATERIAL EXAMINED: Lectotype $\sigma^{7}$ and paralectotype 19 with label "B 378 v24 2sp, DE40"O". Paralectotypes with labels: 2

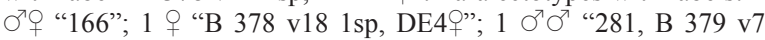
1sp.”; 2 +o “154, B 379 v9 2sp.”; 1 ○ “157, B 379 v8 1sp.”; 4 ○ ठ “153, B 379 v15 4sp.”; 2 우 5 juv. “160, B 379 v19 1sp.”; 1 ○’ 1 juv., 119, B 379 v11 2sp.”; 2 우 “186, B 379 v18 2sp”.

LOCALITIES MENTIONED IN THE TEXT: Kashghar, December 1873; Tanktze to Chagna and Pankong valley, between the 15 th and 21st of September 1873. Between Yangihissar and Sirikol, March 1874; near Leh, August and September 1873. Yangihissar, April 1874. Yarkand and neighbourhood, November 1873. Road from Yarkand to Bursi, May 28th to June 17th, 1874; and road across the Pamir from Sirikol to Panja and back, April 22nd to May 7th, 1874. Hills between Sirikol and Aktalla, May 8th to 13th, 18741; and the Sind Valley, August 5th to 13th, 1873.

ETYMOLOGY. We found no proper translation of this word; it can mean "the pace".

NOTE. Reimoser [1935] considered this species in Scotophaeus, but has not provided any arguments in favour of the transfer.

DIAGNOSIS. Males of this species can be easily distinguished from other species occurring in the region due to the characteristic tibial apophysis subdivided on the tip (Figs 3C-D, 5B). Drassodes dispulsus is most similar to D. bifidus Kovblyuk et Seyyar, 2009 known from Turkey only. The two species have very similar tibial apophyses, course of sperm duct and shape of embolus, but can be distinguished by the dorsal teeth of the tibial apophysis being shorter than the ventral teeth and shorter embolus not extending beyond the tegular apophysis in D. dispulsus (vs. dorsal teeth longer than ventral, embolus relatively longer, and extends beyond the tegular apophysis in D. bifidus). Females of two species differ by higher and thinner median plate in D. dispulsus.

DESCRIPTION (smallest/largest specimens). Male: Total length 7.75 (10.50). Carapace 3.45 (4.75) long, 2.30 (3.35) wide. Chelicerae with 3 promarginal teeth, retromarginal tooth absent.

Length of leg segments in paralectotype $8.00 \mathrm{~mm}$ long.

\begin{tabular}{|l|c|c|c|c|c|c|}
\hline & $\mathrm{Fe}$ & $\mathrm{Pa}$ & $\mathrm{Ti}$ & $\mathrm{Mt}$ & $\mathrm{Ta}$ & Total \\
\hline I & 3.98 & 1.85 & 3.55 & 2.98 & 1.83 & 14.18 \\
\hline II & 3.30 & 1.70 & 3.05 & 2.70 & 1.75 & 12.50 \\
\hline III & 3.05 & 1.50 & 2.43 & 2.65 & 1.48 & 11.10 \\
\hline IV & 4.00 & 1.70 & 3.35 & 4.13 & 1.75 & 14.93 \\
\hline
\end{tabular}

Leg spination (paralectotype): femora I 2(3)d2(0)p, II $2 \mathrm{~d} 1(2,3) \mathrm{p}$, III $3 \mathrm{~d} 2 \mathrm{p} 2 \mathrm{r}$, IV $3 \mathrm{~d} 2 \mathrm{p} 2 \mathrm{r}$; tibia I $1-2 \mathrm{v}$, II $2 \mathrm{p} 2-2 \mathrm{v}$, III $1 \mathrm{~d} 3 \mathrm{p} 3 \mathrm{r} 2-2 \mathrm{v}$, IV $2 \mathrm{~d} 3 \mathrm{p} 3 \mathrm{r} 2-2 \mathrm{v}$; metatarsus I 0, II 1(0)p2v, III 1d3p3r2-2v, IV 1d3p3r2-2v.

Palp as in Figs 3C-D, 4C-D, 5B; femur unmodified; tibia more than 2 times shorter than cymbium, with apophyses 1.2 times shorter than cymbium, tibial apophysis slightly more than 0.5 tibia length, not tapering, with subparallel margins, bifurcated near tip, ventral branch abrupt, dorsal triangle-shaped; cymbium elongate droplet-shaped, 2.2 times longer than wide; tegulum oval, almost 2 times longer than wide; subtegulum hidden by tegulum; tegular apophysis large, as long as embolus; conductor widened near the tip; embolus conical, relatively short (ca. 2 times longer than wide near the base), almost straight, originates at 11 o'clock position.

Female. Total length 7.00 (11.50). Carapace 3.63 (5.20) long, 2.45 (3.60) wide. Chelicerae with 3 promarginal teeth and 1 very small retromarginal tooth.

Length of leg segments (largest specimen measured).

\begin{tabular}{|l|c|c|c|c|c|c|}
\hline & $\mathrm{Fe}$ & $\mathrm{Pa}$ & $\mathrm{Ti}$ & $\mathrm{Mt}$ & $\mathrm{Ta}$ & Total \\
\hline I & 4.13 & 2.28 & 3.38 & 3.00 & 2.13 & 14.90 \\
\hline II & 3.88 & 2.08 & 3.08 & 2.68 & 1.88 & 13.58 \\
\hline III & 3.63 & 1.75 & 3.00 & 3.00 & 1.75 & 13.13 \\
\hline IV & 4.63 & 2.03 & 3.80 & 4.55 & 1.88 & 16.88 \\
\hline
\end{tabular}

Leg spination (paralectotype): femora I $2 \mathrm{~d} 2 \mathrm{p}$, II $2 \mathrm{~d} 2(3) \mathrm{p}$, III $3 \mathrm{~d} 2 \mathrm{p} 2 \mathrm{r}$, IV $3 \mathrm{~d} 2 \mathrm{p} 2 \mathrm{r}$; tibia I $2-2 \mathrm{v}$, II $2 \mathrm{p} 2-2 \mathrm{v}$, III $1 \mathrm{~d} 3 \mathrm{p} 2 \mathrm{r} 2-$ $2 \mathrm{v}$, IV $2 \mathrm{~d} 3 \mathrm{p} 3 \mathrm{r} 2-2 \mathrm{v}$; metatarsus I $2 \mathrm{v}$, II $2-2 \mathrm{v}$, III $3 \mathrm{p} 3 \mathrm{r} 2-2 \mathrm{v}$, IV $1 \mathrm{~d} 3 \mathrm{p} 3 \mathrm{r} 2-2 \mathrm{v}$.

Epigyne as in Figs 6A-C; fovea distinct, 1.7 wider than high; septum wide, inverted trapezium, anterior/posterior width $=1.5$, anterior receptacles exceed anterior margin of fovea; anterior and posterior receptacles almost of the same with, anterior receptacles with short stems.

COMMENTS. This species has more syntypes than any other gnaphosids described in the paper and was therefore easy to recognize.

DISTRIBUTION. WSC [2019] indicates distribution of D. dispulsus as Tajikistan and Mongolia, although it was described from India (Sind Valley, Leh), Xinjiang (several 

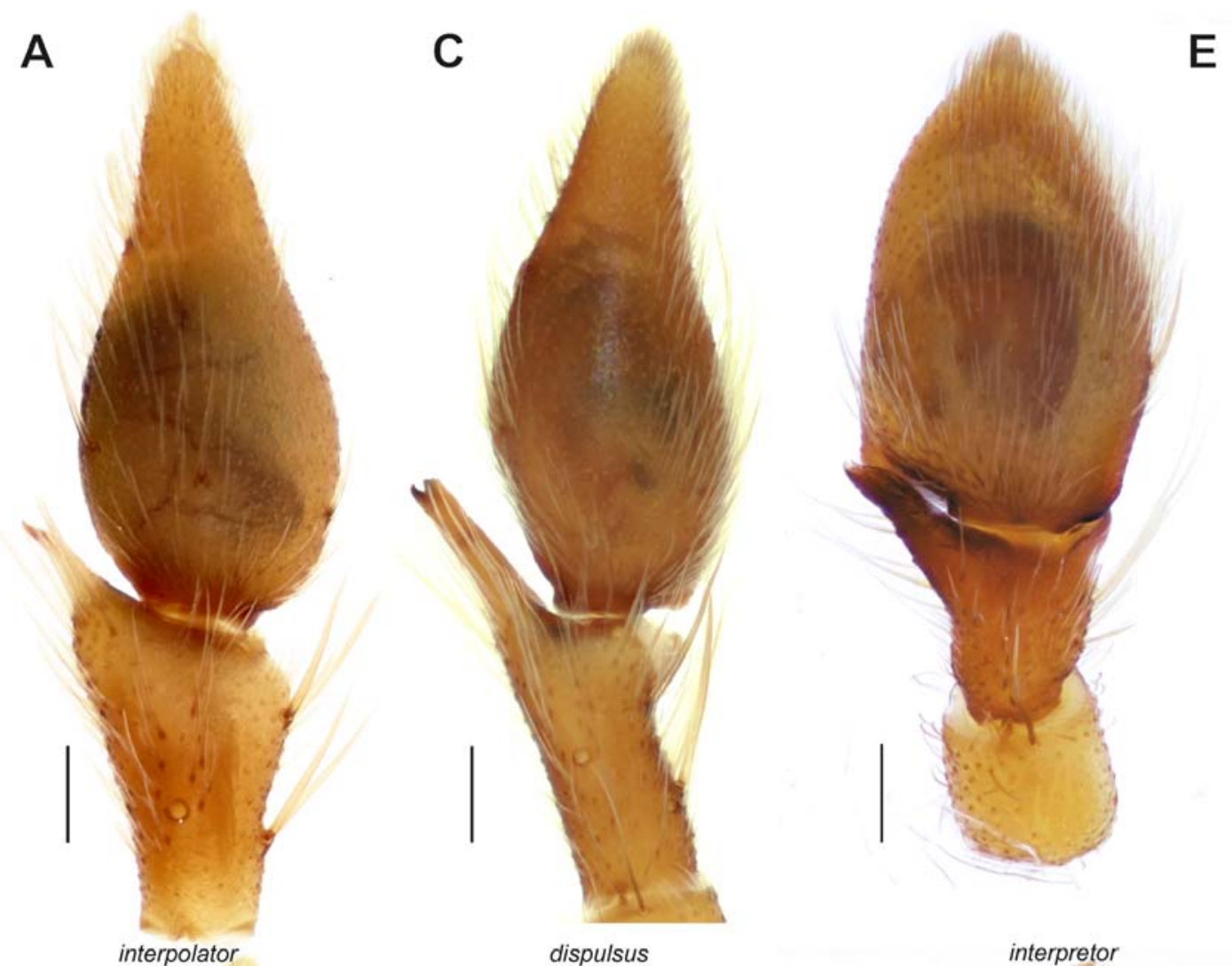

E
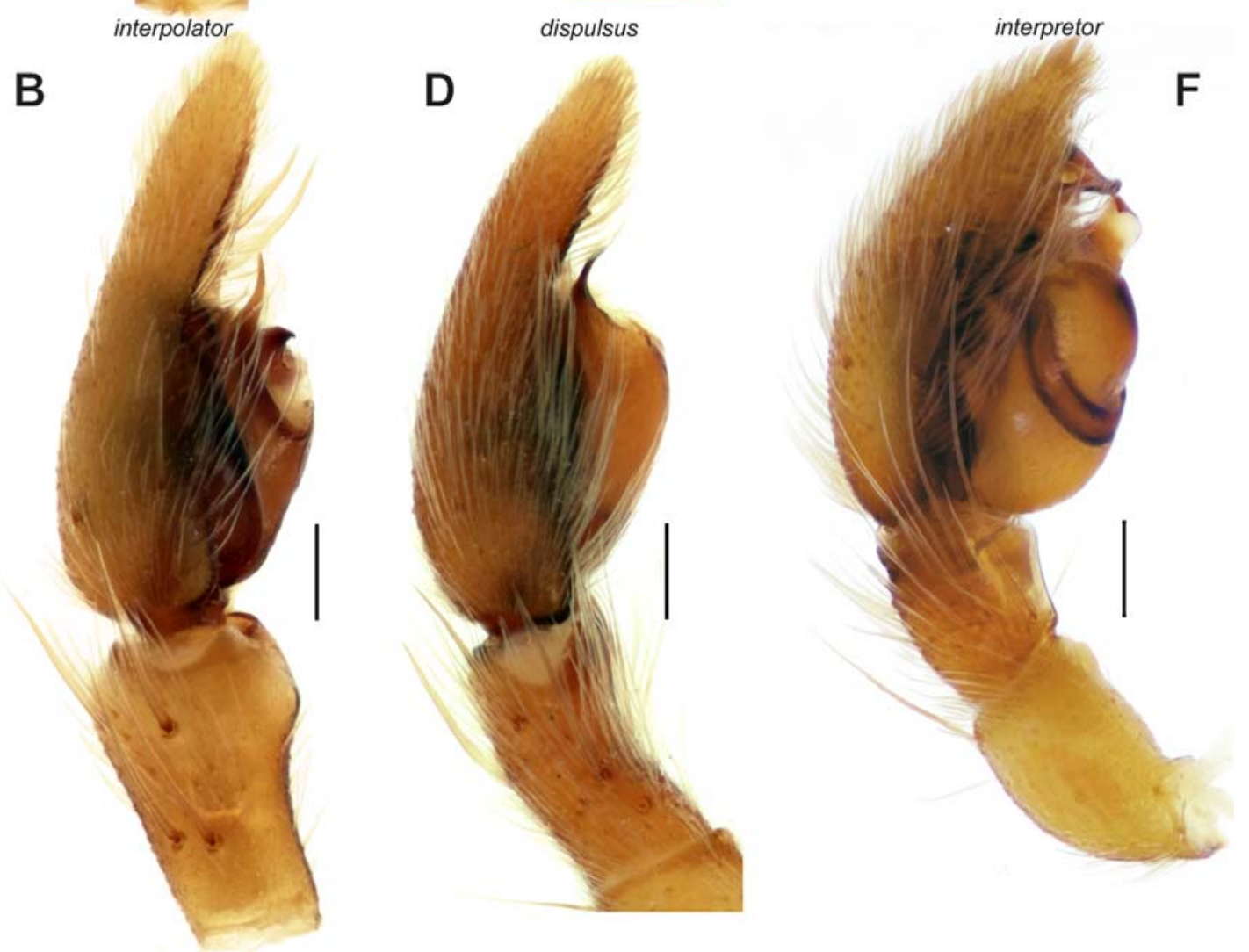

Fig. 4. Male palp of Drassodes interpolator (A, B), D. dispulsus (C, D) and Echemus interemptor (E, F). A, C, E - dorsal view; B, D, $\mathrm{F}$ - prolateral view. Scale $=0.2 \mathrm{~mm}$.

Рис. 4. Пальпа самца Drassodes interpolator (A, В), D. dispulsus (C, D) и Echemus interemptor (E, F). А, С, Е — дорзально; В, D, F - пролатерально. Масштаб 0,2 мм. 

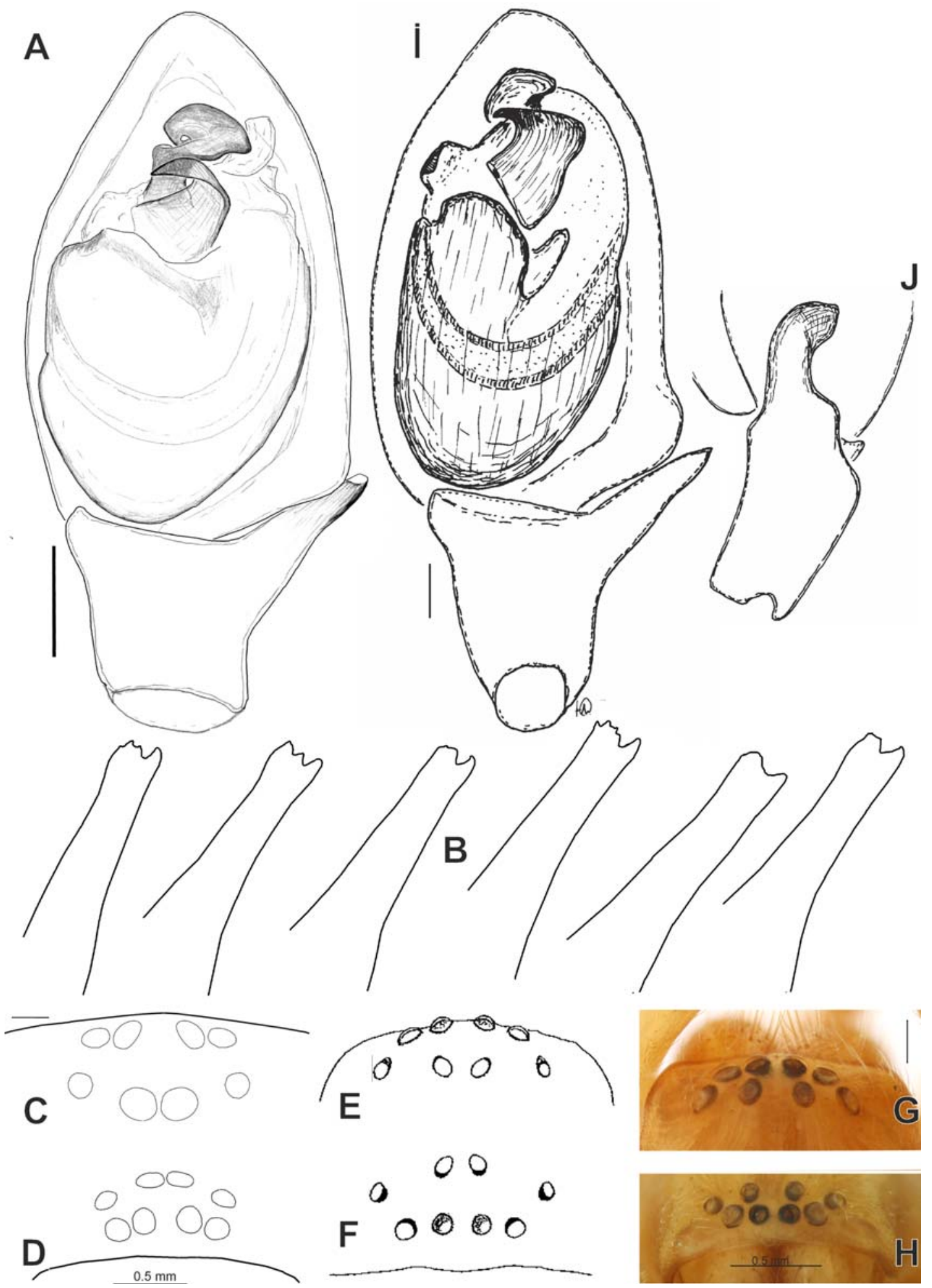

Fig. 5. Palp and eye pattern in Echemus interemptor (A), Drassodes dispulsus (B), D. infletus (C-D), D. lapidosus (E-F), D. involutus $(\mathrm{G}-\mathrm{H})$ and Echemus sibiricus Marusik et Logunov, 1995 (I-J). I-J - after Marusik \& Logunov [1995]. A, I — male palp, ventral; B variation of retrolateral tibial apophysis; C, E, G - eye pattern, dorsal; D, F, H - eye pattern, frontal; J - tibia, retrolateral. Scale $=0.2$ $\mathrm{mm}$, if not otherwise indicated

Рис. 5. Пальпа и глаза Echemus interemptor (A), Drassodes dispulsus (B), D. infletus (C-D), D. lapidosus (E-F), D. involutus (G-H) и Echemus sibiricus Marusik et Logunov, 1995 (I-J). I-J — по Marusik \& Logunov [1995]. A, I — пальпа самца, вентрально; В вариации ретролатерального отростка голени; С, Е, G - глаза, дорзально; D, F, Н — глаза, фронтально; J — голень, ретролатерально. Масштаб 0,2 мм, если не указано иное. 

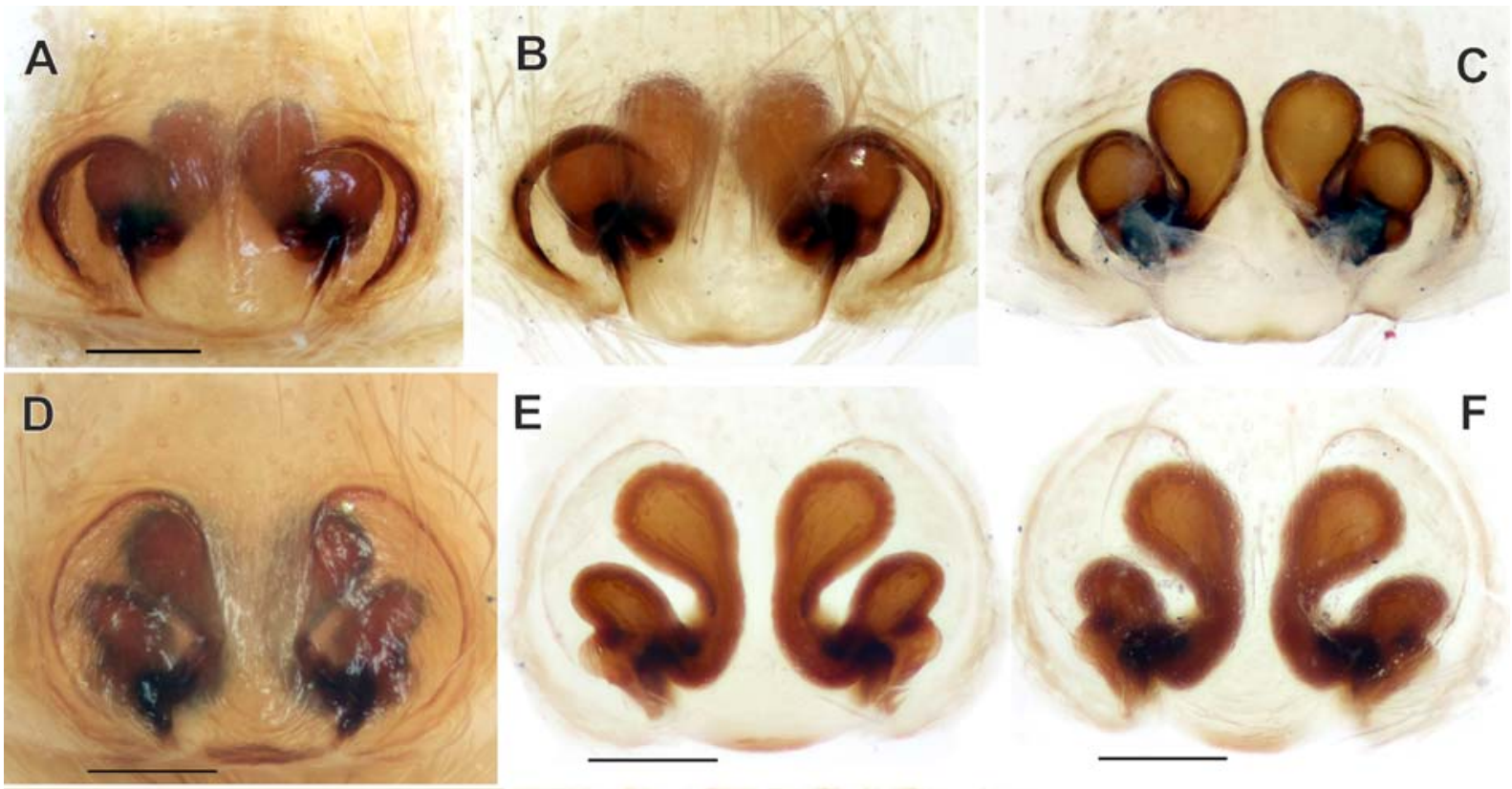

E
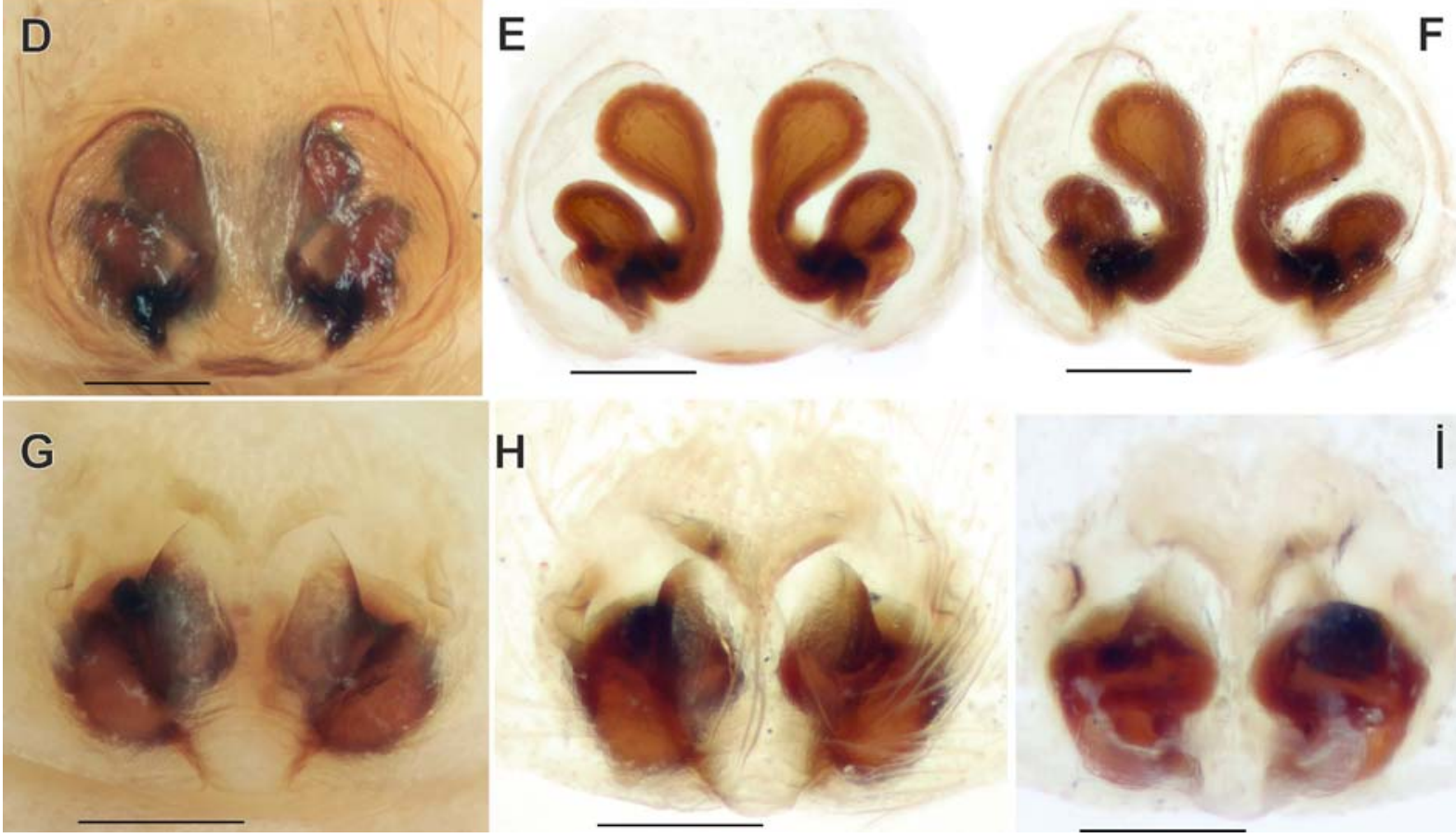

$\mathrm{H}$
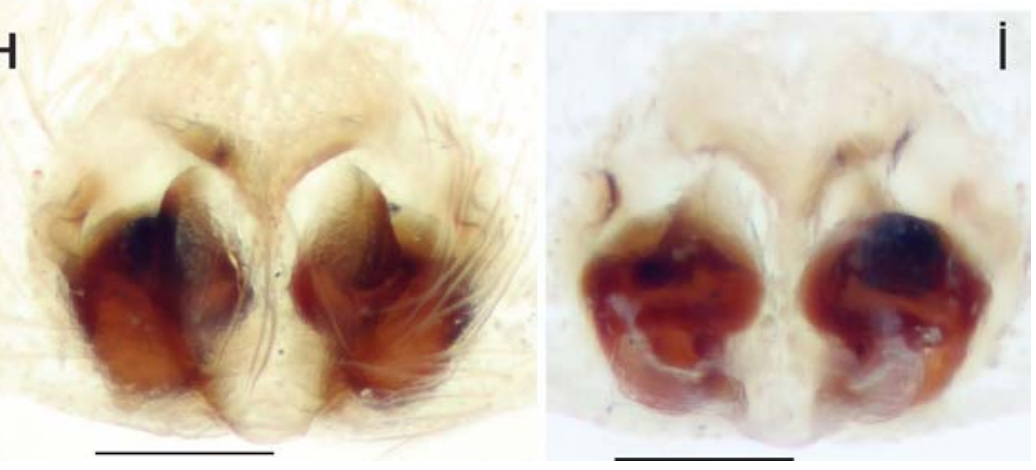

Fig. 6. Epigyne of Drassodes dispulsus (A-C), D. invisus (D-F) and D. involutus (G-I). A, D, G - intact, ventral; B, E, H macerated, ventral; $\mathrm{C}, \mathrm{F}, \mathrm{I}$ - dorsal. Scale $=0.2 \mathrm{~mm}$.

Рис. 6. Эпигина Drassodes dispulsus (A-C), D. invisus (D-F) и D. involutus (G-I). A, D, G - интактная, вентрально; В, Е, Н мацерированная, вентрально; С, F, I - дорзально. Масштаб 0,2 мм.

localities) and either in Afghanistan or Tajikistan (road across Pamir from Sirikol to Panja and back). Schenkel [1936] reported this species from several localities in Inner Mongolia, and Gansu (Lanzhou). Drassodes parauritus, a junior synonym is known from Qinghai and Xinjiang [Li, Lin, 2016]. Thus, there are no any records from Mongolia, and range can be described as Western Himalaya, Pamir to Gansu.

"Drassodes" infletus (O. Pickard-Cambridge, 1885) Figs $1 \mathrm{~B}, 5 \mathrm{C}-\mathrm{D}, 7 \mathrm{C}-\mathrm{L}$.

Drassus i. O. Pickard-Cambridge, 1885: 7, pl. 1, f. 4 (†).

Drassodes i.: Simon, 1893: 361 (transferred to Drassodes); 1895: 332 (reported from Altai).

Drassodes i.: Ermolajev, 1937: 605, f. 6 ( $\odot$, misidentified).

MATERIAL EXAMINED: Syntypes: 1 o with label "110, B 378 v2 1 1sp.”; 2 우 “376, B 376 v14 2sp.”

LOCALITIES MENTIONED IN THE TEXT: Between Yangihissar and Sirikol, March 1874.

ETYMOLOGY. Latin word "infletus" means unmounrned.

DESCRIPTION. Male unknown.
Paralectotype (lectotype). Total length 5.20 (6.80). Carapace 2.18 (2.75) long. 1.58 (2.00) wide. Chelicerae with 3 promarginal and 2 retromarginal teeth. Body without pattern (7I).

Length of leg segments (Paralectotype).

\begin{tabular}{|l|c|c|c|c|c|c|}
\hline & $\mathrm{Fe}$ & $\mathrm{Pa}$ & $\mathrm{Ti}$ & $\mathrm{Mt}$ & $\mathrm{Ta}$ & Total \\
\hline I & 1.36 & 0.86 & 1.21 & 0.87 & 0.71 & 5.01 \\
\hline II & 1.19 & 0.77 & 0.90 & 0.96 & 0.60 & 4.41 \\
\hline III & 1.00 & 0.51 & 0.64 & 0.81 & 0.57 & 3.54 \\
\hline IV & 1.47 & 0.74 & 1.17 & 1.21 & 0.73 & 5.33 \\
\hline
\end{tabular}

Leg spination (paralectotype): femora I $2 \mathrm{~d} 2 \mathrm{p}$, II $2 \mathrm{~d} 1 \mathrm{p}$, III $2 \mathrm{~d} 2 \mathrm{p} 2 \mathrm{r}$, IV $2 \mathrm{~d} 1 \mathrm{p} 1 \mathrm{r}$; tibia I 0, II 0, III $1 \mathrm{~d} 2 \mathrm{p} 2 \mathrm{r} 2-2 \mathrm{v}$, IV 2p3r2-2v; metatarsus I 0, II 0, III 3p2r2-2v, IV 3p3r2-2v.

Epigyne as in Figs $7 \mathrm{C}-\mathrm{H}, \mathrm{J}-\mathrm{L}$; posterior margin with deep triangular notch $(T n)$, fovea large, almost 3 times wide than high; with short triangular anterior extension $(T e)$ of the epigynal plate (covered with setae), anterior part of fovea with rectangular shaped septum $(\mathrm{Se})$, that looks like 

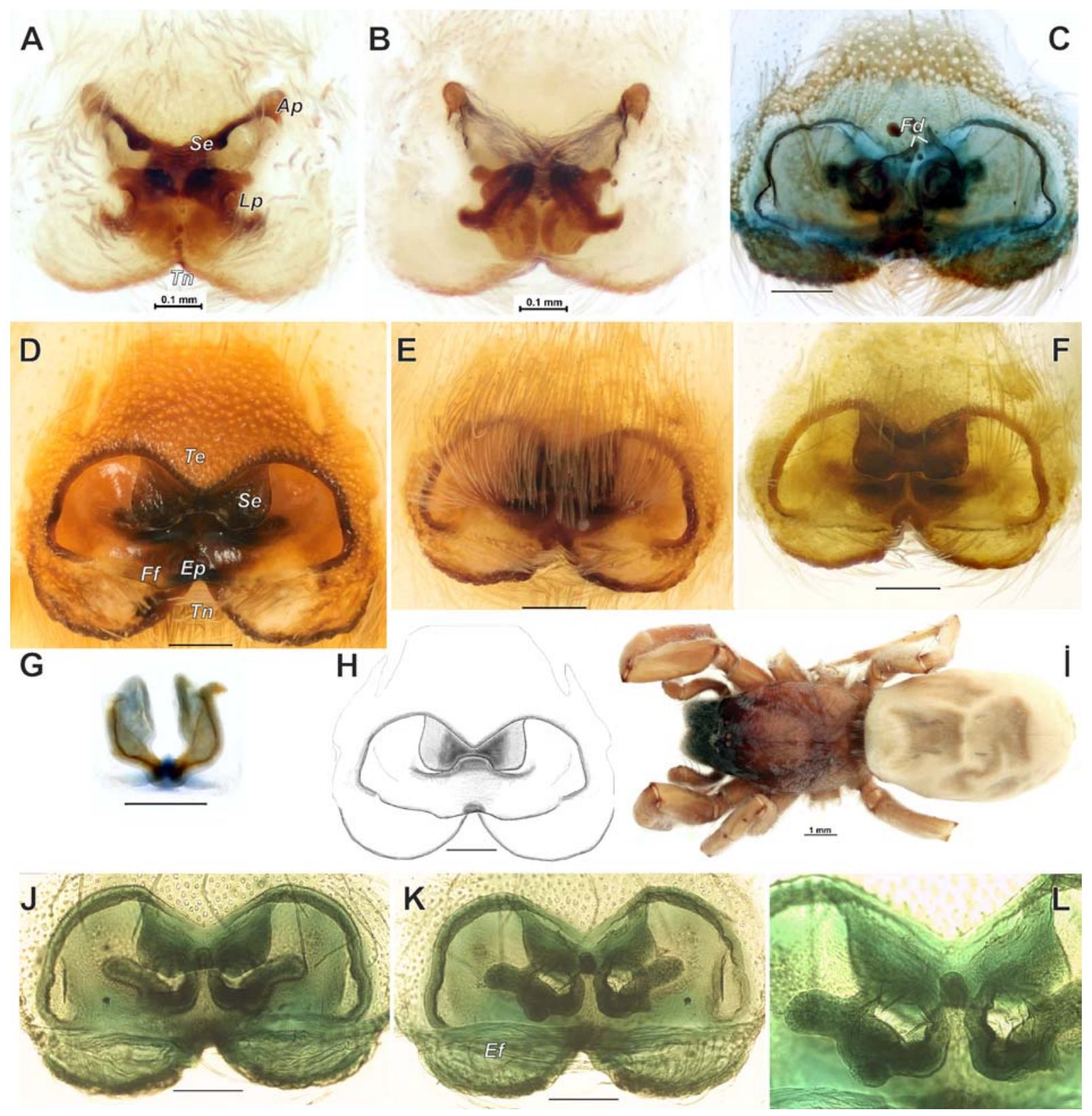

Fig. 7. Females of Coreodrassus interlisus (A, B) and D. infletus (C-L). A, C, J - macerated epigyne, ventral; B, K, L - endogyne, dorsal; D - intact epigyne with removed setae; E — intact epigyne with setae; F — dissected epigyne with removed setae; G fertilization ducts; $\mathrm{H}$ - epigyne, ventral; I — habitus; J - epigyne. J-L — photo made with Olympus BH-2.

Abbreviations: $A p$ - anterior pockets; $E f$ - epigynal fold (rupture); $E p$ - pockets; $F d$ - fertilization ducts; $F f$ - fovea fold; $L p-$ lateral pockets; $S e$ - septum; $T e$ - triangular extension; $T n$ - triangular notch.

Рис. 7. Самки Coreodrassus interlisus (A, В) и D. infletus (C-L). А, С, J- мацерированная эпигина, вентрально; В, К, L эндогина, дорзально; D - интактная эпигина с удалёнными волосками; Е - интактная эпигина с волосками; $\mathrm{F}$ - вычлененная эпигина с удалёнными волосками; G - оплодотворительные каналы; H — эпигина, вентрально; I — внешний вид; J — эпигина. $\mathrm{J}-\mathrm{L}$ - снимки сделанные Olympus BH-2.

Сокращения: $A p$ - передние кармины; $E f$ - складка эпигины; $E p$ - карманы; $F d$ - оплодотворительные каналы; $F f-$ «грыжа» ямки; $L p$ - латеральные карманы; $S e$ - септум; $T e$ - треугольный выступ; $T n$ - треугольная выемка.

part of $T e$, posterior part of septum with round incision; septum hides copulatory openings; copulatory openings large and round; posterior part of fovea extends, fovea and forms fold (rupture) $(F f)$ covering partly posterior part of epigynal plate; $F f$ and $T n$ forms pocket $(E p)$. Posterior edge of epigyne forms deep fold $(E f)$. Receptacle small, transverse, short- er than septal width, copulatory ducts indistinct. Fertilization ducts $(F d)$ large, directed anteriorly, due to the large fold of epigynal plate.

NOTE. While preparing epigyne for photographing fertilization ducts broke down (Fig. $7 \mathrm{G})$. Intact $F d$ are shown on Fig. 7C. 
COMMENTS. This species was considered by Simon [1893: 361] as belonging to D. troglodytes C.L. Koch, 1837 group (= Haplodrassus Chamberlin, 1922). To our mind, it does not belong to Drassodes or Haplodrassus and its relationship remains unclear to us. It has a very unusually complex epigyne and different eye arrangement (cf. Figs 5C-D and 5E-F). Pickard-Cambridge compared this species with $D$. interemptor (here transferred to Echemus) a species described based on the male. The endogyne of this species is somehow similar to that in Echemus angustifrons (Westring, 1861), the type species of the Echemus, and D. infletus may belong to Echemus and could even be conspecific with $D$. interemptor although the distance between the type localities is about $400 \mathrm{~km}$ and there are several mountain ranges between them.

DISTRIBUTION. In WSC [2019] its distribution is indicated as "China (Yarkand), Russia (South Siberia), Mongolia". The record from Russia (Altai, Ermolajev [1937]) is based on misidentification [Fomichev, Marusik, 2011]. The record from Mongolia by Simon [1895] "Steppe de Tschui" refers to the Altai (Chuya steppe) and is also most likely based on a misidentification.

Drassodes interpolator (O. Pickard-Cambridge, 1885) Figs $1 \mathrm{G}, 2 \mathrm{C}, 3 \mathrm{~A}-\mathrm{B}, 4 \mathrm{~A}-\mathrm{B}$.

Drassus i. O. Pickard-Cambridge, 1885: 10, pl. 1, f. 7 ( $\left.\sigma^{7}\right)$. MATERIAL EXAMINED: Holotype $\sigma^{7}$ with label "208, B 378 V $151 \mathrm{sp}, \mathrm{DE} 3 \mathrm{O}^{\text {T" }}$

LOCALITIES MENTIONED IN THE TEXT: Hills between Sirikol and Aktalla, between the 8th and 13th of May 1874, and on the road across the Pamir from Sirikol to Panja and back between April the 22nd and May the 7th, 1874

DESCRIPTION. Holotype male. Total length 8.70. Carapace 3.88 long, 2.78 wide. Chelicerae with 3 promarginal teeth and retromarginal tooth absent. Abdomen and carapace without pattern.

Length of leg segments (? - refers to missing segment).

\begin{tabular}{|l|c|c|c|c|c|c|}
\hline & $\mathrm{Fe}$ & $\mathrm{Pa}$ & $\mathrm{Ti}$ & $\mathrm{Mt}$ & $\mathrm{Ta}$ & Total \\
\hline I & $?$ & $?$ & $?$ & $?$ & $?$ & - \\
\hline II & 3.50 & 1.73 & $?$ & $?$ & $?$ & - \\
\hline III & 3.38 & 1.38 & 2.93 & 3.28 & 1.75 & 12.70 \\
\hline IV & 4.38 & 1.80 & 3.68 & 4.73 & 1.88 & 16.45 \\
\hline
\end{tabular}

Leg spination (? - refers to missing segment): femora I ?, II $3 \mathrm{~d} 3 \mathrm{p} 1 \mathrm{r}$, III $3 \mathrm{~d} 1 \mathrm{p} 3 \mathrm{r}$, IV $3 \mathrm{~d} 2 \mathrm{p} 2 \mathrm{r}$; tibia I ?, II ?, III 1d2p3r2-2v, IV 2d3p3r2-2v; metatarsus I ?, II ?, III 1d3p3r2$2 \mathrm{v}$, IV $3 \mathrm{~d} 3 \mathrm{p} 2 \mathrm{r} 2-2 \mathrm{v}$.

Palp as in Figs 3A-B, 4A-B; tibia over 2 times longer than wide proximally, distal part swollen, tibial apophysis not strongly sclerotised, subconical; cymbium elongate, droplet-shaped; subtegulum not hidden by tegulum; tegular apophysis large, square shaped, wider than tibial apophysis; conductor straight, not bent; embolus long and straight, longer than $1 / 2$ of the tegulum, displaced from the prolateral edge of the tegulum.

DISTRIBUTION. WSC [2019] indicates its distribution as Tajikistan, China (Yarkand) although it was described and is known by the holotype only. The locality indicated in the text could refer to Afghanistan, or Tajikistan or Xinjiang. It would be more correct statement to write "Pamir".
“Drassodes” involutus (O. Pickard-Cambridge, 1885) Figs $1 \mathrm{H}, 2 \mathrm{E}, 5 \mathrm{G}-\mathrm{H}, 6 \mathrm{G}-\mathrm{I}$.

Drassus i. O. Pickard-Cambridge, 1885: 14, pl. 1, f. 10 (). MATERIAL EXAMINED: Syntypes: 2 + + with labels “140, B 381 V3 1sp" and "B 378 v2 1sp, D54".

LOCALITY MENTIONED IN THE TEXT: Sind Valley, August 5 th to 13 th, 1873 .

ETYMOLOGY. Latin word "involutus" means rolled up or wrapped up.

DESCRIPTION. Male unknown.

Female (syntypes). Total length 7.15 (6.98). Carapace 3.10 (3.13) long. 2.25 (2.33) wide. Chelicerae with 3 promarginal and 2 retromarginal teeth. Carapace and abdomen without pattern.

Length of leg segments (specimen 7.15 long).

\begin{tabular}{|l|c|c|c|c|c|c|}
\hline & $\mathrm{Fe}$ & $\mathrm{Pa}$ & $\mathrm{Ti}$ & $\mathrm{Mt}$ & $\mathrm{Ta}$ & Total \\
\hline I & 2.85 & 1.55 & 2.48 & 1.90 & 1.15 & 9.93 \\
\hline II & 2.38 & 1.33 & 2.10 & 1.78 & 1.00 & 8.58 \\
\hline III & 3.10 & 1.40 & 2.60 & 3.38 & 1.25 & 11.73 \\
\hline IV & 3.03 & 1.50 & 2.63 & 3.35 & damaged & - \\
\hline
\end{tabular}

Leg spination: femora I $2 \mathrm{~d} 2 \mathrm{p}$, II $2 \mathrm{~d} 2 \mathrm{p}$, III $3 \mathrm{~d} 2 \mathrm{p} 2 \mathrm{r}$, IV $3 \mathrm{~d} 2 \mathrm{p} 2 \mathrm{r}$; tibia I 2-2v, II 2-2v, III 1d3p2r2-2v, IV 1d3p3r2$2 \mathrm{v}$; metatarsus I $2 \mathrm{v}$, II $2-2 \mathrm{v}$, III $3 \mathrm{p} 3 \mathrm{r} 2-2 \mathrm{v}$, IV $3 \mathrm{p} 3 \mathrm{r} 2-2 \mathrm{v}$.

Epigyne as in Figs 6G-I; fovea without lateral margins, but with 2 anterior hoods, and pair of lateral pits; septum wide, more than $1 / 2$ of fovea width, tapering posteriorly; endogyne with one pair of subglobular receptacles.

COMMENTS. Judging from the shape of epigyne: presence of anterior pockets and lateral pits, lack of distinct lateral margins of fovea, and one pair of receptacles this species does not belong to Drassodes. Eye pattern of this species differs from those in D. lapidosus, the type species of the genus.

DISTRIBUTION. The WSC [2019] indicates it distribution as China (Yarkand), although it was described from the Sind Valley and may refer either to modern Pakistan or India.

Drassodes invisus (O. Pickard-Cambridge, 1885) Figs 1C, 2A, 6D-F.

Drassus invisus O. Pickard-Cambridge, 1885: 9, pl. 1, f. $6(+)$. Drassus lapsus O. Pickard-Cambridge, 1885: 15, pl. 2, f. 11 (juvㅇ). Syn.n.

Scotophaeus invisus: Reimoser, 1935: 173.

D. lapsus: Hogg, 1912: 205, f. 5 (क, identification doubted by author).

MATERIAL EXAMINED. Drassodes invisus: Lectotype $q$ and paralectotypes 2 우 11 juv. with label “44, B 379 v21 14sp."; $D$. lapsus: holotype subadult female was not recognized among the material.

LOCALITY MENTIONED IN THE TEXT: Drassodes invisus: Between Sirikol and Aktalla, between the 8th and 31st of May 1874; D. lapsus: Yangihissar, April 1874.

ETYMOLOGY. Latin word "invisus" means hated.

NOTE. Reimoser [1935] considered D. invisus to be in Scotophaeus but has not provided any arguments in support of the transfer. The two species have been synonymized because they come from the same region and because it is not possible to determine which species the subadult female (holotype of D. lapsus) is. 
DESCRIPTION. Male unknown.

Female. Lectotype/smallest paratype. Total length 10.60 (9.4). Carapace 5.00 (4.62) long, 3.50 (3.05) wide. Chelicerae with 3 promarginal teeth, retromargin without teeth. Body lacking pattern.

Length of leg segments (lectotype).

\begin{tabular}{|l|c|c|c|c|c|c|}
\hline & $\mathrm{Fe}$ & $\mathrm{Pa}$ & $\mathrm{Ti}$ & $\mathrm{Mt}$ & $\mathrm{Ta}$ & Total \\
\hline I & 4.35 & 2.35 & 4.03 & 3.38 & 2.00 & 16.10 \\
\hline II & 4.05 & 2.15 & 3.90 & 3.18 & 2.00 & 15.28 \\
\hline III & 3.98 & 1.93 & 3.28 & 3.43 & 2.00 & 14.60 \\
\hline IV & 4.95 & 2.15 & 4.53 & 5.25 & 2.23 & 19.11 \\
\hline
\end{tabular}

Leg spination: femora I $2 \mathrm{~d} 2 \mathrm{p}$, II $2 \mathrm{~d} 2 \mathrm{p}$, III $3 \mathrm{~d} 2 \mathrm{p} 2 \mathrm{r}$, IV $3 \mathrm{~d} 2 \mathrm{p} 2 \mathrm{r}$; tibia I $2-2 \mathrm{v}$, II $1(2) \mathrm{p} 2-2 \mathrm{v}$, III $1 \mathrm{~d} 3 \mathrm{p} 3 \mathrm{r} 2-2 \mathrm{v}$, IV $2 \mathrm{~d} 2 \mathrm{p} 3 \mathrm{r} 2-2 \mathrm{v}$; metatarsus I $2 \mathrm{v}$, II $2 \mathrm{v}$, III $3 \mathrm{~d} 2 \mathrm{p} 2 \mathrm{r} 2-2 \mathrm{v}$, IV $3 \mathrm{~d} 2 \mathrm{p} 2 \mathrm{r} 2-2 \mathrm{v}$.

Epigyne as in Figs 6D-F; fovea large, width-height ratio ca. 1.57 and receptacles do not extend beyond the anterior margins, septum well developed, anterior width about $1 / 4$ of fovea width, base of septum 2.5 times thinner than fovea width; anterior and posterior receptacles not touching each other; anterior receptacles with distinct stem, over 2 times thinner than receptacle diameter.

COMMENT. Drassodes invisus could be a synonym of $D$. interpolator, a species known from male only. Two species have the same type locality.

DISTRIBUTION. This species is known from the type locality only.

\section{Echemus Simon, 1878}

TYPE SPECIES: Drassus angustifrons Westring, 1861 from Sweden.

COMMENTS. Currently 22 species are assigned to this poorly known genus, and most of them it seems are misplaced. It has global distribution, and its species are described from Australia, Southeast Asia, Siberia, India, Europe, Africa and Brazil. Only six species are described by both sexes, two are known only by juveniles. Furthermore, only half species are illustrated. Nineteen species are known only from the original description. Currently males of only five species are more or less well illustrated, but as to females, only in one, the type species, is the epigyne properly illustrated. The genus has no somatic characters that allow it to be distinguished from other genera, but can be recognized thanks to the male palp. While searching for literature on this genus we recognized that African E. incinctus Simon, 1907 has a palpclosely resembling that in the type species of Hongkongia Song et Zhu, 1998, H. wuae Song et Zhu, 1998 and therefore we suggest new combination Hongkongia incinctus (Simon, 1907), comb.n.

\section{Echemus interemptor (O. Pickard-Cambridge, 1885), comb.n.}

Figs 1D, 2D, 3E-F, 4E-F, 5A.

Drassus i. O. Pickard-Cambridge, 1885: 8, pl. 1, f. $5\left(\sigma^{7}\right)$. MATERIAL EXAMINED: Holotype $\sigma^{7}$ with label "78, B 378 v16 1sp, DS2" in poor condition most of leg segments are detached.

LOCALITIES MENTIONED IN THE TEXT. Neighbourhood of Leh, August or September 1873.
ETYMOLOGY. Latin word "interemptor" means killer or murderer.

DIAGNOSIS. This species is most close to E. sibiricus Marusik et Logunov, 1995 (Figs 5I-J) a species known from Tuva only. The two species differ in the shape of tibial apophysis and its tip: apophysis straight with small extension on the tip in E. interemptor (Fig. 3F) and bent and without extension on the tip in E. sibiricus (Fig. 5J). Echemus interemptor also differs from sibling species by having a wider embolus.

DESCRIPTION. Total length 7.40. Carapace 3.50 long. 2.53 wide. Chelicerae with 3 promarginal teeth and 1 small retromarginal tooth. Carapace and abdomen without pattern.

Length of leg segments (? - refers to missing segment).

\begin{tabular}{|l|c|c|c|c|c|c|}
\hline & $\mathrm{Fe}$ & $\mathrm{Pa}$ & $\mathrm{Ti}$ & $\mathrm{Mt}$ & $\mathrm{Ta}$ & Total \\
\hline I & \multicolumn{7}{|c|}{ missing } & - \\
\hline II & 2.63 & 1.50 & $?$ & $?$ & $?$ & - \\
\hline III & 2.28 & 1.28 & 2.00 & 1.80 & 1.13 & 8.49 \\
\hline IV & 3.00 & $?$ & $?$ & $?$ & $?$ & - \\
\hline
\end{tabular}

Leg spination (? - refers to missing segment): femora I $3 \mathrm{~d} 1 \mathrm{p}$, II $3 \mathrm{~d} 2 \mathrm{p} 1 \mathrm{r}$, III $3 \mathrm{~d} 2 \mathrm{p} 2 \mathrm{r}$, IV $3 \mathrm{~d} 2 \mathrm{p} 1 \mathrm{r}$; tibia I ?, II ?, III 1d3p3r2-2v, IV ?; metatarsus I ?, II ?, III 3p3r2-2v, IV ?.

Palp as in Figs 3E-F, 4E-F, 5A; tibia short, almost as wide as long (not counting apophysis); apophysis as long as tibia, flattened, almost 3 times longer than wide, with small extension dorso-anteriorly; cymbium with short tip and basoretrolateral triangular extension; sperm duct semi round, not meandering and not reaching posterior or retrolateral edge of the tegulum; conductor membranous, almost indistinct, wide; embolus flat and twisted around its axis, originates anteriorly in the middle of the tegulum.

COMMENTS. We transfer this species to Echemus due to its similarity with the two Asian species E. sibiricus and E. levyi Kovblyuk et Seyyar, 2009 and also with the generotype, E. angustifrons (Westring, 1861). While describing Drassus interemptor O. Pickard-Cambridge compared it with $D$. infletus known only by females collected from Xinjiang. Endogyne of $D$. infletus with transversal receptacles is somewhat similar to those in E. angustifrons, and therefore $E$. interemptor could be conspecific with $D$. infletus.

DISTRIBUTION. WSC [2019] indicate its distribution as Yarkand, although the species was described and known so far only from India (Leh).

\section{Gen. Micaria Westring, 1851}

\section{Micaria lenzi Bösenberg, 1899 Figs 1I, 8A-D.}

M. connexa O. Pickard-Cambridge, 1885: 20 ( $\left.\sigma^{7}+\right)$. Syn.n. M. pallida O. Pickard-Cambridge, 1885: 20 (j). Syn.n. M. lenzi: Wunderlich, 1980: 277, f. 6, 29a-d, 51a-c ( $\left.{ }^{7}+\right)$.

M. lenzi: Mikhailov, Marusik, 1995: 102, f. 31-32, 37 ( ${ }^{7}+$ ).

M. lenzi: Song et al., 2004: 174, f. 102A-E ( $\left.\sigma^{7}+\right)$.

M. lenzi: Almquist, 2006: 437, f. 376a-e ( $\left.\sigma^{\top}+\right)$.

For complete list of taxonomic references (altogether 20) for M. lenzi see WSC [2019].

MATERIAL EXAMINED. Lectotype of $M$. connexa $\sigma^{\top}$ (designated here) with the label "226, tube IV. Transferred from B.378". Female syntype not found.

LOCALITIES MENTIONED IN THE TEXT: $M$. connexa: Hills between Sirikol and Aktalla, May 8th to 13th, 1874; M. pallida: 

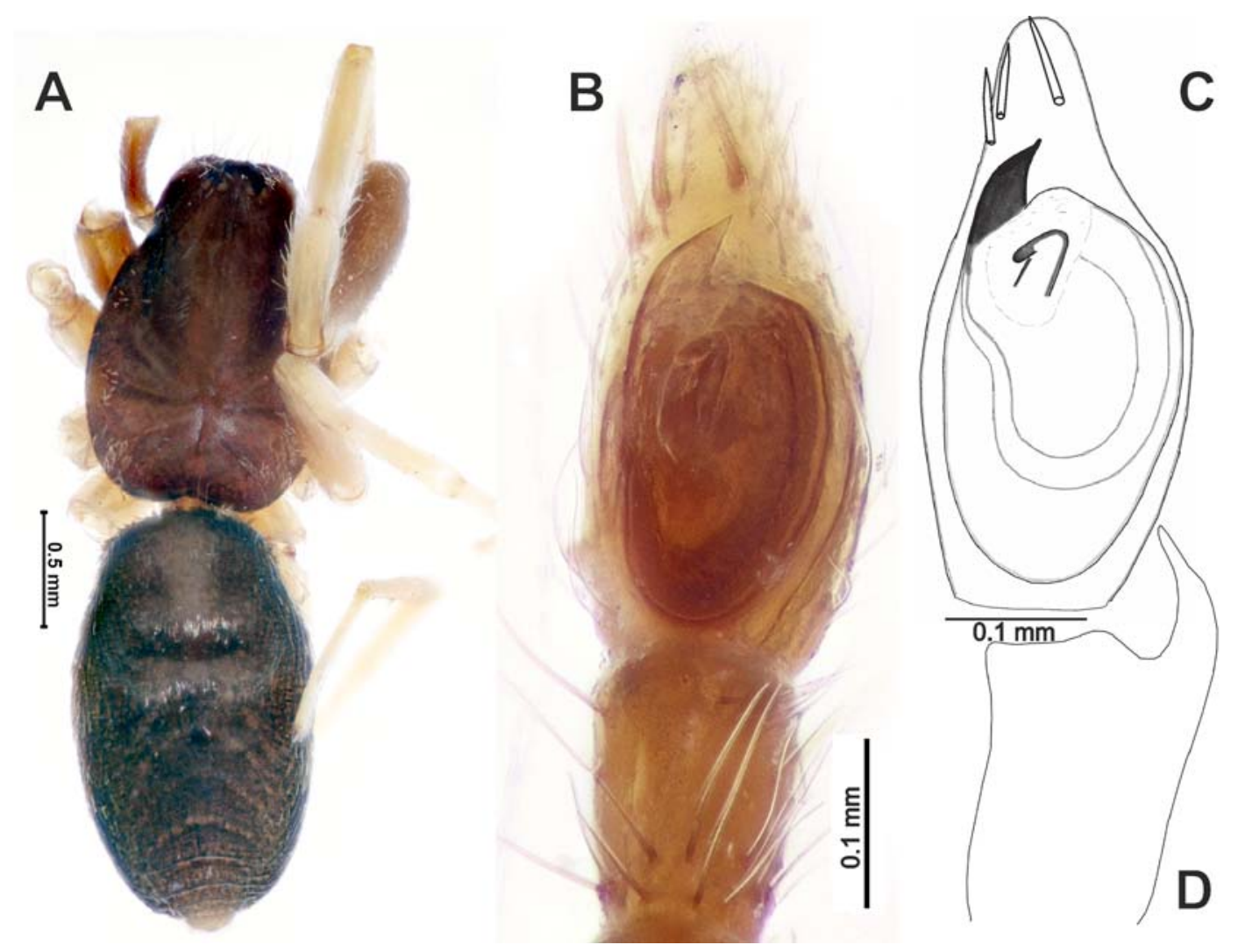

Fig. 8. Holotype of Micaria connexa (A-B) and Micaria lenzi (C-D, from Magadan). A - habitus, dorsal; B - male palpal tibia and tarsus, ventral; $\mathrm{C}$ - male palpal tarsus, ventral; D - male palpal tibia, retrolateral.

Рис. 8. Голотип Micaria connexa (A-B) и Micaria lenzi (C-D, из Магадана). А — внешний вид, дорзально; В — голень и лапка пальпы самца, вентрально; C — лапка пальпы самца, вентрально; D — голень пальпы самца, ретролатерально.

Found on the route across the Pamir from Sirikol to Panja and back, April 22nd.

COMMENTS. Micaria lenzi is widespread Palaearctic species [Marusik et al., 2000]. Although it was described after M. connexa and M. pallida, the name should be preserved because of lack of usage of the senior synonyms (only used in original description) and numerous citations of M. lenzi in taxonomic and faunistic papers [ICZN, 2019: Art. 23.9.1].

Male palp of the lectotype $M$. connexa has no differences with those of $M$. lenzi. While describing new species $\mathrm{O}$. Pickard-Cambridge [1885] mentioned its similarity to $M$. pulicaria, as a species having a similar palp. Moreover $M$. lenzi is known from Tibet, Xinjiang [Song et al., 2004] and also in Himalaya [Marusik et al., 2014]. Although, M. palli$d a$ was described based on the subadult male, we synonymize it with $M$. lenzi because this species occurs in the region and it is impossible to recognize juveniles in this genus.

DISTIBUTION. Micaria lenzi has trans-Palaearctic distribution. The WSC [2019] indicates type locality of $M$. pallida as Tajikistan but collecting locality "across the Pamir from Sirikol to Panja and back" may refer either to Afghanistan (from Sirikol to Panja) or Tajikistan (back).

Acknowledgements. We thank Zoë Simmons (Oxford, UK) and Dmitri V. Logunov (Manchester, UK) for their help both in obtaining spider material from the Second Yarkand Mission, and in searching the archive of O. Pick-
ard-Cambridge for notes or transcripts that that would allow us to decipher the numerical labels associated with specimens. Special thanks go to Seppo Koponen and Ilari Sääksjärvi (ZMUT) for providing us with museum facilities; as well as to Seppo Koponen, Mykola M. Kovblyuk (Simferopol, Crimea) and an anonymous reviewer whose comments allowed us to improve our paper. We thank also Zhang Feng (Baoding, China) and Alexander Ponomarev (Rostov-onDon, Russia) for providing us with comparative figures and specimens. The English of the final draft was kindly checked by Zoë Simmons.

\section{References}

Almquist S. 2006. Swedish Araneae, part 2 - families Dictynidae to Salticidae // Insect Systematics \& Evolution, Supplement. Vol.63. P.285-601.

Bonnet P. 1956. Bibliographia araneorum. Toulouse: Douladure. T.2. Pt.2. P.919-1926.

Ermolajev W. 1937. Beitrag zur Kenntnis der altaischen Spinnen // Festschrift Embrik Strand. Bd.3. S.596-606.

Fomichev A.A., Marusik Yu.M. 2011. New data on spiders (Arachnida: Aranei) of the Altai Republic, Russia // Arthropoda Selecta. Vol.20. No.2. P.117-123.

Hogg H.R. 1912. Araneidae // Clarck R.S., Sowerby A. de C. (eds.). Clark Expedition to northern China. London: Through Shên-kan. P.204-218.

Hu J.L. 2001. Spiders in Qinghai-Tibet Plateau of China. Henan Science and Technology Publishing House. 658 p. 
Hu J.L., Wu W.G. 1989. Spiders from agricultural regions of Xinjiang Uygur Autonomous Region, China. Jinan: Shandong University Publishing House. 435 p.

International Code of Zoological Nomenclature. 2019. Fourth Edition. online at http://www.iczn.org/iczn/index.jsp, accessed on 20.05.2019.

Li S.Q., Lin Y.C. 2016. [Species Catalogue of China. Volume 3. Animalia. Invertebrata (I). Arachnida: Araneae]. Beijing: Science Press. 578 pp. [In Chinese]

Marusik Yu.M. 1993. [Redescription of spiders of the families Heteropodidae and Thomisidae (Aranei), described by O. P. Cambridge from the material of the second Yarkand mission] // Entomologicheskoye Obozrenie. Vol.72. P.456-468 [in Russian].

Marusik Yu.M. 2017. Redescription of Dysdera cylindrica (Aranei: Dysderidae) a single known species of the family in Pakistan with notes on the distribution of the family // Arthropoda Selecta. Vol.26. P.310-314.

Marusik Yu.M., Logunov D.V. 1995. Gnaphosid spiders from Tuva and adjacent territories, Russia // Beiträge zur Araneologie. Bd.4. P.177-210

Marusik Yu.M., Logunov D.V., Koponen S. 2000. Spiders of Tuva, south Siberia. Magadan: Institute for Biological Problems of the North. 253 pp.

Marusik Yu.M., Nadolny A.A. 2018. Redescription of enigmatic spider genus Stoliczka O. Pickard-Cambridge, 1885 (Araneae: Lycosoidea) based on the type species // Zootaxa. Vol.4497. P.295-300. doi:10.11646/zootaxa.4497.2.9

Marusik Yu.M., Omelko M.M. 2014. A survey of East Palaearctic Gnaphosidae (Araneae). 3. On new and poorly known Gnaphosa Latreille, 1804 // Zootaxa. Vol.3894. P.10-32. doi:10. 11646/zootaxa.3894.1.4

Marusik Yu.M., Omelko M.M. 2018. A survey of the Porrhoclubiona Lohmander, 1944 from Central Asia (Araneae, Clubiondae [sic]) // ZooKeys. Vol.802. P.19-38.

Marusik Yu.M., Omelko M.M., Koponen S. 2018. Redescription of Himalayan Trachelas costatus (Araneae: Trachelidae) // Zootaxa. Vol.4433. P.390-392.

Marusik Yu.M., Zonstein S. 2019. Redescription of the Central Asian spider Pholcoides seclusa comb. nov. (Araneae: Filistatidae) // Arachnologische Mitteilungen. Vol.57. P.43-47.

Mikhailov K.G., Marusik Yu.M. 1996. [Spiders of the north-east of the USSR. Families Clubionidae, Zoridae, Liocranidae and Gnaphosidae (genus Micaria) (Arachnida, Aranei)] // Entomologicheskie issledovaniya na Severo-Vostoke SSSR. Vladivos- tok: Institute of Biological Problems of the North. P.90-113 [in Russian, with English summary; dated "1991"].

Ovtsharenko V.I., Platnick N.I., Song D.X. 1992. A review of the North Asian ground spiders of the genus Gnaphosa (Araneae, Gnaphosidae) // Bulletin of the American Museum of Natural History. Vol.212. P.1-88.

Pickard-Cambridge O. 1885. Araneidea // Scientific results of the second Yarkand mission; based upon the collections and notes of the late Ferdinand Stoliczka. Calcutta: Government of India. 115 p. doi:10.5962/bhl.title. 119960

Proszyński J., Żochowska K. 1981. Redescriptions of the O. P.Cambridge Salticidae (Araneae) types from Yarkand, China // Polskie Pismo Entomologiczne. Vol.51. P.13-35.

Reimoser E. 1919. Katalog der echten Spinnen (Araneae) des Paläarktischen Gebietes // Abhandlungen der Zoologisch-Botanischen Gesellschaft in Wien. Bd.10. H.2. S.1-280.

Reimoser E. 1935. Araneida // Wissenschaftliche Ergebnisse der niederländischen Expeditionen in den Karakorum. Leipzig: Zoologie. S.169-176.

Schenkel E. 1936. Schwedisch-chinesische wissenschaftliche Expedition nach den nordwestlichen Provinzen Chinas, unter Leitung von Dr Sven Hedin und Prof. Sü Ping-chang. Araneae gesammelt vom schwedischen Artz der Exped // Arkiv för Zoologi. Bd.29. S.1-314.

Schenkel E. 1963. Ostasiatische Spinnen aus dem Muséum d'Histoire naturelle de Paris // Mémoires du Muséum National d'Histoire Naturelle de Paris (A, Zool.). Vol.25. P.1-481.

Simon E. 1893. Histoire naturelle das araignées. Paris. Vol.1. P.257488 .

Simon E. 1895. Arachnides recueillis par M. G. Potanine en Chinie et en Mongolie (1876-1879) // Bulletin de l'Académie impériale des sciences de St.-Pétersbourg. Vol.5. No.2. P.331-345.

Song D.X., Zhu M.S., Zhang F. 2004. Fauna Sinica: Invertebrata Vol.39: Arachnida: Araneae: Gnaphosidae. Beijing: Science Press. 362 p.

World Spider Catalog. 2019. World Spider Catalog. Natural History Museum Bern, online at http://wsc.nmbe.ch, version 20.0, accessed on 20.05.2019.

Wunderlich J. 1980. Revision der europäischen Arten der Gattung Micaria Westring 1851, mit Anmerkungen zu den übrigen paläarktischen Arten (Arachnida: Araneida: Gnaphosidae) // Zoologische Beiträge (N.F.). Vol.25. P.233-341.

Responsible editor S. Koponen 